Studia z Dziejów Średniowiecza, t. 23, 2019

\author{
Mariola Freza-Olczyk \\ (Instytut Historii, Uniwersytet Gdański) \\ https://orcid.org/0000-0001-5088-9475
}

\title{
Stepmother and stepson: Duchess Matilda in the power struggle after the death of her husband Barnim I, the Duke of Pomerania
}

https://doi.org/10.26881/sds.2019.23.03

Keywords: Duchy of Pomerania, Duchess Matilda, Duke Barnim I, Duke Bogusław IV, margraves of Brandenburg

This article explores the political relationship between some of the most prominent figures of the Duchy of Pomerania in the $13^{\text {th }}$ century. The first part presents general information about the origins of Duke Barnim I, his son Duke Bogusław IV, and Duchess Matilda. The subsequent part shows their political activity and achievements as rulers. The family background had an immense influence on each one's decisions. The pivotal point of the last section of this paper is to elaborate the political struggle between Duke Bogusław IV and his stepmother, Duchess Matilda.

According to sources, Barnim I wasmarie tree times ${ }^{1}$. Edward Rymar claims that his first wife Marianna was a daughter of King

1 G. Sello, Chronica Marchionum Brandenburgensium. Nach einer Handschrift der Trierer Stadtbibliothek und den Excerpten des Pulkawa [in:] Forschungen zur Brandenburgischen und Preußischen Geschichte, Bd. 1, Leipzig 1888, p. 126; see also: PU, Bd. 1, no. 401 (29 March 1242); Bd. 2, no. 702 (25 May 1261). Margaret was only mentioned after her death; M.L. Wójcik, Ród Gryfitów do końca XIII wieku. Pochodzenie - genealogia - rozsiedlenie, Wrocław 1993, p. 39. Barnim was a ruler of the Griffin dynasty in Western Pomerania in the $13^{\text {th }}$ century. He was a son of Duke Bogusław II and Duchess Mirosława, who was a daughter of Duke Mestwin of Pomerelia. The first formal mention of Marianna can be found in the document of Cistercians from Uznam (a Baltic Sea island in Pomerania); E. Rymar, Rodowód ksiażat pomorskich, Szczecin 2005, pp. 143-151. 
Eric X of Sweden and Richeza of Denmark. The main purpose of this marriage was to improve relations with Sweden and Denmark. It was regarded as an opportunity to end recent hostilities ${ }^{2}$. Before her death, Marianna gave birth only to daughters. The lack of a male descendant was the main reason for Barnim entering into a subsequent marriage. His second wife, Duchess Margaret, was a daughter of Nicholas I, member of the House of Mecklenburg. Margaret brought him a son and successor, Bogusław IV. His exact date of birth is unknown, although academics believe it was before 1258. Bogusław reached the age of majority around 1272 (this date is also open to doubt). He was mentioned for the first time with Barnim I in a document of the 4 June 1273 that could be evidence of his early involvement in politics ${ }^{3}$. However, having only one male heir was insufficient for Duke Barnim. In the beginning of the 1260s Duchess Margaret died; not long after, in 1264, do did, childless, his cousin, Duke Warcisław III ${ }^{4}$. As a ruler Barnim was obliged to protect his duchy, and thus decided to remarry. On 20 June 1236 Duke Warcisław III signed the Treaty of Kremmen and accepted the margraves of Brandenburg as his feudal lords, giving them Stargard, Wustrow, and Beseritz. He thus recognised their rule over Pomerania-Demmin. For the Margraviate of Brandenburg, obtaining access to these lands was a significant opportunity. Duke Barnim was aware of the danger resulting from this arrangement; hence, his third choice of wife was not random ${ }^{5}$.

2 PU, Bd. 1, no. 352. A Papal dispensation was required for this marriage because there was a forbidden propinquity between Barnim and Marianna in the fourth degree, for more see: E. Rymar, Królewna szwedzka Marianna na tronie zachodniopomorskim w latach 1238-1252, ZH 1980, z. 45, pp. 16-21; L. Ulwencreutz, Ulwencreutz's royal families in Europe V: A brief history of the ruling houses during the last 2000 years. From the house of La Tour d'Auvergne to the house of Zähringen, Ulwencreutz Media 2013, p. 373.

3 PU, Bd. 6, no. 3465. We know of his appearance in 1273 from the copy of a document made by Duke Warcisław IV in 1321. In the original document from 1273 there is only a passing remark about Barnim and unnamed successors; E. Rymar, Matgorzata - druga żona Barnima I, "Materiały Zachodniopomorskie" 1975, t. 21, pp. 338-339; idem, Rodowód..., pp. 159-161.

4 PU, Bd. 2, no. 702: "Pro remedio animae [...] dominae Margaretae"; see: no. 751-753. Warcisław's last documents of the 17 May 1264. See also: no. 759. Duke Barnim mentioned him in the document of the 10 September 1264: "Pro anima cognate nostri W. quondam ducis Dyminensis".

5 MUB, Bd. 1, no. 457; J. Schultze, Die Mark Brandenburg, Bd. 1, Berlin 1961, p. 142; E. Rymar, Między układem kremmeńskim i landyńskim (1236-1250). Wojna Pomorza Zachodniego z Rugiq i Brandenburgia, RH 1987, R. 52, pp. 134-135, 138-139; J. Spors, Geneza i poczatki brandenburskiego zwierzchnictwa lennego nad Pomorzem 
Duchess Matilda was Barnim's last wife and a daughter of Otto III, Margrave of Brandenburg, and Beatrice of Bohemia ${ }^{6}$. The Duke solemnised his marriage around 1266. The exact date of Matilda's birth is still unknown; scholars stipulate that it was between 1245 and 1250 . The reasons for entering into this particular marriage were the desire to have more male descendants and to ameliorate the conflict with the Margraviate of Brandenburg. Although the marriage did not last long, they had four daughters and two sons, including Duke Barnim II and Duke Otto I7 . Barnim's death in 1278 began joint reigns - Duke Bogusław IV had to share his power with younger half-brothers and his stepmother, Duchess Matilda. Bogusław IV died in 1309, Matilda in $1316^{8}$. Numerous conflicts between the Duchy of Pomerania and the Margraviate of Brandenburg arose as a result of clashing interests. The period of Matilda's and Barnim's reign was marked by several political disagreements that will be presented below.

The precise date of the marriage between the Pomeranian duke and the duchess from Mecklenburg is uncertain; some documents suggest it took place between 1263 and 1267. Duke Barnim was ceratinly already a widower in 1261, as on 25 May 1261 he wrote a document for the intention of his second wife, Duchess Margaret ${ }^{9}$. Barnim mentioned again Duchess Margaret when he wrote a document for the Cistercians from

Zachodnim na tle rywalizacji o ziemie nad środkowa Odra $i$ dolna Warta $w$ latach 1234-1261 [in:] Studia nad wczesnośredniowiecznymi dziejami Pomorza Zachodniego, XII-pierwsza połowa XIII w., Słupsk 1988, pp. 300, 361, 366; E. Rymar, Ksiażęta zachodniopomorscy wobec obronności swego państwa w XII-XIII wieku [in:] Pomorze militarne XII-XXI w., red. E. Rymar, K. Kozłowski, Szczecin 2004, p. 145. The scholar asserts that the main reason for the conclusion of the Treaty of Kremmen in 1236 was Mecklenburg's invasion of Pommerania-Demmin; E. Rymar, Rodowód..., pp. 144-145. The Pomeranian duke probably wanted to improve his political contacts with the Margraviate of Brandenburg. While Barnim had control over the Duchy of Pomerania with the main centre in Szczecin, his cousin Warcisław III was responsible for the Duchy of Pomerania with the centre in Demmin. However, owing to lack of descendants, his part of the duchy ceased to exist. Barnim took over the reign after his cousin's death.

6 F. Escher, Otto III, Markgraf von Brandenburg [in:] Neue Deutsche Biographie, Bd. 19, Berlin 1999, pp. 676-677. Otto III was a son of Albert II, Margrave of Brandenburg and a member of the House of Ascania. His mother, Matilda of Lusatia, was a daughter of Count Conrad II from the House of Wettin. Matilda's mother, Beatrice of Bohemia, was a daughter of King Wenceslaus I of Bohemia, who was married to Kunigunde of Hohenstaufen.

7 E. Rymar, Rodowód..., pp. 150-151; J.R. Lyon, Princely brothers and sisters: The sibling bond in German politics, 1100-1250, New York 2013, p. 241.

8 PU, Bd. 4, no. 2462. The Duke was mentioned as dead. See also: Bd. 5, no. 3037.

9 PU, Bd. 2, no. 702 . 
Szczecin on March $1263^{10}$. There is no mention of Duchess Matilda until 20 May $1267^{11}$. The Pomeranian chronicler Thomas Kantzow asserts that Duchess Margaret died in 1263; this, however, is not possible, as already in a document of 1261 she is mentioned as dead ${ }^{12}$. Matilda was probably mentioned for the first time in Barnim's document in 1267, which speaks of chaplain Conrad with an unknown lady - and according to other documents, Conrad Duchess Matilda's chaplain from the village of Krevese in Saxony-Anhalt, Germany. This can be evidence that Duke Barnim was already married to her ${ }^{13}$.

According to Rymar, in 1269 Duke Barnim was in a conflict with his minor son Bogusław IV, who resided in Mecklenburg with his grandfather Nicholas I, the Lord of Werle ${ }^{14}$. This could indeed be proof that possibly new descendants of Duke Barnim were born. Furthermore, it could also provide an explanation for why Bogusław left his father. Barnim's adolescent son probably felt unsafe because of his step-siblings. What is more, Duke Barnim could have had a future wife for his son in mind and in all likelihood his choice went against Bogusław's wishes, causing a significant family conflict. There is, however, no evidence in support of such a theory.

During the period of 1268-1269 there was also strife between Duke Barnim and the Cistercians on the one side and the Knights

$10 \quad$ Ibidem, no. 734 .

11 Ibidem, no. 841.

12 T. Kantzow, Chronik von Pommern in hochdeutscher Mundart, Bd. 1, hrsg. G. Gaebel, Stettin 1897, p. 160: "1263 (VII kal. April) ist auch Margareta, Barnims Gemahel, gestorben und im Junckfrawencloster zu Stettin begraben worden. Darnach hat er Mechtild, eine von Brandenburg genhomen. Hirnach im Jar 1264 ist gestorben Herzog Wartislaff". See also: PU, Bd. 2, no. 702 (25 May 1261): "Pro remedio ac salute animae dilectae uxoris nostrae dominae Margaretae".

13 S.A. Wolf, Ueber die Gaue des hannoverschen Wendlandes, "Zeitschrift f. Geschichteswissenschaft" 1956, H. 4, p. 103. Siegmund A. Wolf mentions that Kribzi is a village Kriwitz situated in the area of Luchow; W. Hessler, Mitteldeutsche Gaue d. frühen und hohen Mittelalter, "Abhandlungen der Sachsischen Akademie der Wissenschaften zu Leipzig. Philologisch-historische Klasse” 1957, Bd. 49, H. 2, p. 133. According to Wolfgang Hessler, the village Kribzi is the same village as Creuse (Krevese) in the north of Osterburg and in the east of Salzwedel. See also: PU, Bd. 2, no. 841: "Conradus prepositus de Creuese capellanus domine"; G. Labuda, Fragmenty dziejów Stowiańszczyzny zachodniej, t. 3, Poznań 1975, p. 168. Gerard Labuda underlines that both opinions, Wolf's as well as Hessler's, are acceptable; E. Rymar, Rodowód..., p. 150 , ref. $38-330$.

14 F. Wigger, Stammtafeln des Großherzoglichen Hauses von Meklenburg, "Jahrbücher des Vereins für Mecklenburgische Geschichte und Altertumskunde" 1885, Bd. 50, p. 222; PU, Bd. 4, no. 3970; E. Rymar, Rodowód..., p. 159. 
Hospitaller and the margraves of Brandenburg on the other. The Knights Hospitaller came into possession of lands that belonged to the Cistercians. Marek Smoliński gives a detailed chronology of this conflict. According to him, this political strife started in 1266, when Duke Barnim got into debt with the Knights Hospitaller. Barnim probably put in pledge some of his lands. The monks made a complaint to Pope Clemens IV, who sent Albert the Great, former Bishop of Regensburg, to Western Pomerania. Duke Barnim with his vassals and the Cistercian abbot of Kołbacz were excommunicated in 1269. Moreover, they had to return the lands to the Knights Hospitaller. In 1271 Pope Clemens IV upheld his decision of $1269^{15}$. According to sources, the margraves of Brandenburg expelled the Cistercians from the village of Sowina: "Marchiones monachos nostros et converses de Sovin violenter ejecerunt et adhuc retinent absque jure" 16 .

Scholars claim that during the first months of 1269 political contacts between Barnim and the margraves of Brandenburg were fairly stable. However, in June 1269, after the agreement of Margrave Otto V and the dukes of Mecklenburg, the political situation was becoming increasingly complicated ${ }^{17}$. In accordance with this agreement, Otto V, who was Matilda's brother, appeared with an archbishop as intermediaries in the ensuing conflict. Meanwhile, Duke Barnim was already married to Duchess Matilda. On 23 August 1269 the Pomeranian Duke used his wife's seal in a document to the church in Lübeck ${ }^{18}$.

15 P. Niessen, Geschichte der Neumark im Zeitalter ihrer Entstehung und Besiedlung. Von den ältesten Zeiten bis zum Aussterben der Askanier, Landsberg 1905, p. 224; H. Frederichs, Herzog Barnim I. im Streit mit dem Johanniterorden, "Baltische Studien” 1934, Bd. 35, p. 257; J. Spors, Dzieje polityczne ziem sławieńskiej, stupskiej i białogardzkiej XII-XIV w., Poznań 1973, pp. 134-136. According to academics, the conflict concerned the lands located in the borderland of Western Pomerania and the New March that belonged to Knights Hospitallers, which the Cistercians took over with the help of Duke Barnim; D. Wybranowski, Jeszcze raz o konflikcie Barnima I z joannitami ze Stargardu i Korytowa z lat 1268-1271. Próba identyfikacji wasali ksiażęcych z dokumentów Alberta Wielkiego, PZ 2001, z. 16, pp. 7-12; M. Smoliński, Joannici w polityce ksiażat polskich i pomorskich od połowy XII do pierwszego ćwierćwiecza XIV wieku, Gdańsk 2008, pp. 209-211.

16 Annalen und Abt-Reihe des Klosters Colbatz. Todtenbuch und Abt-Reihe des Klosters Neuencamp, hrsg. R. Prümers [in:] PU, Bd. 1, Abt. 2, Stettin 1877, p. 485.

17 J. Spors, Dzieje polityczne..., p. 135; E. Rymar, Itinerarium ksiażat pomorskich Barnima I (1220/1221-1278) i Warcisława III (1219/1220-1264), PZ 2008, z. 23, p. 19; M. Smoliński, Joannici..., p. 210.

18 PU, Bd. 2, no. 894. 
Władysław Sobociński asserts that female rulers had to turn over the custody of their minor children to the oldest descendant if they reached majority (the primacy of the oldest family member). In case of step-siblings from different mothers, they had the right to the custody of minors, provided that minors had their own lands inherited from their father. After Duke Barnim's death, his oldest son Bogusław IV had custody of his underage brothers until $1295^{19}$. The scholar specifies the forms of representing minor rulers' interests in documents and underlines the presence of the legal guardian and the minor together in documents or the presence of the legal guardian alone or on the minor's behalf - in such a case, the person who had custody of someone was responsible for the effects of his actions (an example of indirect character). Some documents did not include information about such responsibility (an example of direct character) ${ }^{20}$.

Another crucial issue are the various examples of titles used by Pomeranian rulers. Dukes from Eastern Pomerania as well as Western Pomerania called themselves Pomeranian rulers ( $d u x$ for men, ducissa for women). Titles began to change by the end of the $12^{\text {th }}$ century $^{21}$. The most common title of Duke Barnim was dux Slauorum ${ }^{22}$. He also called himself a Pomeranorum dux $x^{23}$, dux de Stetin ${ }^{24}$, dux Slauorum de Stetin ${ }^{25}$, or dux Pomeranie dominus in Stetin ${ }^{26}$, and in 1267 he was named dux Slauorum et Cassubie $e^{27}$.The term "Cassubia" appeared for the first time in a document of Pope Gregory IX in 1238, in which Duke Bogusław I was mentioned as a dux Cassubie $^{28}$. According to scholars, Duke Barnim I had a seal with a Latin inscription: S. BARNIM DEI

19 W. Sobociński, Historia rzqdów opiekuńczych w Polsce, CPH 1949, t. 2, p. 279.

20 Ibidem, pp. 313-314. According to Sobociński, some of Matilda's documents are examples of direct character, see: PU, Bd. 2, nos. 1128, 1149 (1279); Bd. 3, no. 1609 (1292).

21 P. Czaplewski, Tytulatura ksiażat pomorskich, ZH 1949, t. 15, p. 21.

22 He used this title in numerous documents until his death, see e.g.: PU, Bd. 1, nos. 295, 304, 306, 309, 311, 322-334, 350, 377, 401, 413, 434, 446, 461, 470, 494, 511, 527, 541, 554; Bd. 2, nos. 580, 585, 600, 612, 663, 695, 700, 710, 730, 758, 780, 792, 804, 826, 840, 871, 882, 895, 916, 920, 937, 970, 990, 1002, 1020, 1037, 1051, 1078, 1094, 1112, and many others.

23 Ibidem, Bd. 1, nos. 250, 257, 362, 373, 394, 405, 415, 417, 419, 426, 452, 568; Bd. 2, nos. 577, 590, 598, 608, 610, 611, 618.

${ }_{24}$ Ibidem, Bd. 1, nos. 429, 542, 543, 545, 559, 566; Bd. 2, nos. 595, 596, 620, 630, 821, 841, 885, 896, 1032, 1033, 1075.

$25 \quad$ Ibidem, Bd. 1, no. 451; Bd. 2, nos. 629, 659, 757, 1113.

26 Ibidem, Bd. 1, no. 540.

27 Ibidem, Bd. 2, no. 847.

28 Ibidem, Bd. 1, no. 355. 
GRACIA ILLVSTRIS SLAVORVM. DVCIS. With time, his inscription changed to: S. BARNIM DEI GRACIA ILLVSTRIS SLAVORVM DVCIS. This fact was probably connected with the death of his cousin Warcisław III in 1264. Barnim united his part of the duchy with Warcisław's lands ${ }^{29}$. The title of $d u x$ Slauorum et Cassubie was frequently used in Duke Bogusław's documents ${ }^{30}$. He also appeared as a Pomeranorum dux ${ }^{31}$, dux Slauorum et Stetynensis ${ }^{32}$, dux Stetinensis ${ }^{33}$, and as dux Stettyn, Cassubie et Slauorum ${ }^{34}$. Duke Bogusław IV also had a seal with an inscription: S' BVGVZLAI DEI GRATIA ILLVST[RI]S DVCIS SLAVOR[UM ET] KASSVBI[E] ${ }^{35}$.

An analysis of the documents and seals mentioned above shows that Duke Barnim I and his son both used the title of the Slavic and Cassubian ruler. According to Paweł Czaplewski, the former was connected with the word "Sława", which refers to the Baltic borderland. The word "Slavic" refers to the land of Weleti and the Obodrites. This title was also used by Duchess Ingegerd and Duchess Mirosława ${ }^{36}$.

The most common titles in Duchess Matilda's documents are ducissa Slauorum ${ }^{37}$ and ducissa Stetinensis ${ }^{38}$. She used the title ducissa Slavorum et Cassubie in 1302. Her son, Duke Otto, mentioned his mother as a ducissae Slauorum et Cassubiae in $1297^{39}$. Matilda was titled a Slavic ruler, just as her husband and her stepson, and had a seal with the title of a Cassubian ruler as well. The key idea behind using seals in medieval Europe by noblewomen was to express authority and

29 P. Czaplewski, Tytulatura..., pp. 30-31; G. Labuda, Kaszubi i ich dzieje. Pisma wybrane, Gdańsk 1996, pp. 91, 140.

30 PU, Bd. 2, nos. 1208, 1221, 1300; Bd. 3, nos. 1568, 1588, 1592, 1598, 1601, 16123, 1627, 1661, 1662, 1664, 1669, 1678, 1681, 1732, 1735, 1737, 1771, 1783, 1806, 1832, 1866, 1871, 1883, 1885, 1901, 1902, 1904, 1907, 1932, 1953, 1956, 1957, 1124a, 1680a.

$31 \quad$ Ibidem, Bd. 2, nos. 1124, 1207.

32 Ibidem, no. 1243; Bd. 3, no. 1413.

33 Ibidem, Bd. 3, no. 1477.

34 Ibidem, Bd. 3, nos. 1277, 1282, 1294.

35 E. Rymar, Rodowód..., p. 159.

36 P. Czaplewski, Tytulatura..., p. 28; A. Gut, Formularz dokumentów ksiażat zachodniopomorskich do potowy XIV w., Szczecin 2002, pp. 73-74.

37 PU, Bd. 2, nos. 1218, 1149; Bd. 3, no. 1609; Bd. 4, nos. 1790, 1845. As a Slavic duchess she was mentioned by her son Duke Otto, see: Bd. 4, nos. 1895, 1912.

38 Ibidem, Bd. 4, no. 2309. Duchess Matilda appeared as a ruler from Szczecin in a document of margrave Albert III (Bd. 3, no. 1804), in a document of Duke Bogusław IV (no. 1885), and several times in documents of her son Otto (Bd. 4, nos. 2087, 2091, 2142, 2257; Bd. 5, nos. 2798, 2809, 2879).

39 Ibidem, Bd. 3, no. 1791; Bd. 4, no. 2028. 
involvement in the political sphere. Female rulers emphasised power by showing filiation ${ }^{40}$. In many cases duchesses had their own seals before they were married ${ }^{41}$.

Barnim's third wife had her own majestic seal that presented her sitting on the throne with outstretched arms. In the left hand she holds a shield with a griffin, and in the right a helmet. Duchess Matilda's seal presents her ancestry. The symbol of the griffin relates to the Duchy of Pomerania, while the helmet symbolises the Margraviate of Brandenburg. Matilda's seal is damaged and we can hardly see the Latin inscription: [S] MECH[TI]L[DIS DEI] GRA[CIA] ILLV[STRI DVCISSE SLAVORVM CAS] SVUBIE ${ }^{42}$.

With her majestic seal Matilda accentuated the character of her mission. On the one hand it gives a picture of a representative of balanced politics; on the other, she is presented as a sole ruler, sitting on the throne as an emperess. It can also be interpreted as a demonstration of her power against Duke Bogusław IV and evidence of their conflict. As already mentioned, Barnim confirmed the sale of

40 A. Livingstone, Powerful allies and dangerous adversaries. Noblewomen in medieval society [in:] Women in medieval Western European culture, ed. L.E. Mitchell, New York-London 2011, p. 24; M. Schaus, Women and gender in medieval Europe: An encyclopedia, New York 2016, p. 732.

41 T. Kantzow, Chronik von Pommern..., p. 150, ref. 2; K. Ratajczak, Edukacja kobiet $w$ kręu dynastii piastowskiej $w$ średniowieczu, Poznań 2005, pp. 30-31; E. Rymar, Rodowód..., pp. 145-146. Kantzow asserts that Barnim's first wife Marianna also had a seal that appeared on her document in 1243. However, there is no image of that seal. According to a Pomeranian chronicler, Marianna was presented on the throne with a falcon on her right arm. On her left side was a shield with the image of a lion, while on her right side was a shield with the image of a griffin. According to Rymar, the griffin symbolises the family of her husband, while the lion was connected with her own origins.

42 PU, Bd. 2, no. 894; see also: K. Jasiński, Mirosława (zm. około 1240.), córka Mściwoja I, księcia Pomorza Gdańskiego, żona Bogusława II, księcia szczecińskiego [in:] Ludzie pomorskiego średniowiecza. Szkice biograficzne, red. J. Borzyszkowski, Gdańsk 1981, p. 83; J. Pakulski, Zaginiona pieczęć księżnej mazowieckiej Perejasławy z 1276 r. a trzynastowieczne sigilla księżnej dzielnicowej [in:] Nihil Superfluum esse. Prace z dziejów średniowiecza ofiarowane Profesor Jadwidze Krzyżaniakowej, Poznań 2000, p. 257; A. Rusakiewicz, Najdawniejsze godta ksiażat wschodniopomorskich: lilia i gryf, "Gdańskie Studia z Dziejów Średniowiecza" 2002, t. 9, p. 155-156. Duchess Matilda was not the only one with a majestic a seal. Duke Barnim's mother Mirosława also had her own seal. The Pomeranian duchess was portrayed with her adolescent son. On the impression of her seal from 1229, she gives Barnim a streamer with the symbol of a griffin and a sceptre that looks as a lily. Agnieszka Rusakiewicz interprets it as an example of investiture. The inscription says: MIROSLAVA DEI GRA[CIA] DVCISSA POMERANIE. 
John Romel's lands to the church in Lübeck in 1269. The same person is mentioned, this time as Johanne Ramulo compatre nostro, on 26 February 1269 as a witness ${ }^{43}$. According to some studies, the use of the word compatre could mean that Duke Barnim already had children with Matilda ${ }^{44}$. We can assume that Duchess Matilda was involved in her brother's decision to become a mediator between her husband and her cousins. The fact that she bore a child could have had considerable significance and improved her status at that time ${ }^{45}$.

Matilda did not appear in Barnim's documents often. He mentioned her for the first time namelessly on 20 May 1267, then on 23 August 1269, and the last time on 6 February 1278, before her husband's death ${ }^{46}$. In 1269 Duke Bogusław IV resided in Mecklenburg with his grandfather, Nicholas Werle. According to the document, "dominum Nicolaum de Werle filium Barnim domini Stetinensis debere restituere, si ipsum pater duxerit requirendum" ${ }^{47}$. As mentioned before, this could be a sign of a family conflict between Duke Barnim and the adolescent Bogusław, in all likelihood caused by the birth of new descendants of the Pomeranian Duke. There is also another possibility. Bogusław's presence in Magdeburg might have

43 PU, Bd. 2, no. 878.

44 E. Rymar, Rodowód..., p. 163; K. Guzikowski, Obce rycerstwo na Pomorzu Zachodnim do poczatku XIV wieku, Szczecin 2013, pp. 110, 126. Krzysztof Guzikowski asserts that John Rahmel was married from 1280 to Mirosława, widow of Casimir, Castellan of Kołobrzeg (a town in West Pomerania).

45 John Rahmel was mentioned as a compatre only once, on the 26 February 1269 , see: PU, Bd. 2, no. 878. It could be evidence that this time Barnim's child was born. See also: E. Rymar, Krewni i powinowaci ksiażat pomorskich w źródtach średniowiecznch (XII - poczatek XVI w.), "Materiały Zachodniopomorskie" 1985, t. 31, p. 234. Rymar explains the concept of compatre - according to him, compatre means a "godfather".

46 She was mentioned in 1267, then in 1269 , and for the last time in 1278 , before her husband's death, see: PU, Bd. 2, nos. 841, 894, 1085. In documents she appears as uxoris. Duke Barnim mentioned his previous wives, Marianna and Margaret, as dilecte. Only Marianna, though, was presented as a donator. Barnim mentioned her twice after her death, both times as dilecte - the last time, in 1254, as dilecte quondam uxoris. The Duke was probably already married to his second wife at the time, Duchess Margaret. Margaret appeared in Barnim's documents only after her death in 1261 and 1263 . He also names her dilectae uxoris. We can assume that the relations between Matilda and Barnim were not as close as between the Duke and his previous wives, especially Marianna. His relations with the margraves of Brandenburg could have had some impact on his marriage. Her last mention in 1278 could be related to the fact she was pregnant and thus regained her husband's attention. Her last son, Otto, was a posthumous child.

47 PU, Bd. 4, no. 3970. 
been related with the political conflict which involved Barnim. Since Bogusław was the only male descendant of Barnim, the Duke send him to his grandfather in order not to lose him. However, he had the right to have his son returned. The Pomeranian Duke was probably afraid that the Margrave of Mecklenburg will preclude his return. Duchess Matilda tried to help her husband and sent to Magdeburg her brother, Margrave Otto V. When Duke Barnim died in November in 1278, his son Bogusław had already attained the age of majority, while his other two sons, Barnim II and Otto I, were still underage ${ }^{48}$. Duke Bogusław was mentioned for the first time with Barnim II and Otto on 18 January $1280^{49}$. Nonetheless, some of his documents show that he did not accept the political views of his stepmother and her family.

Before Barnim died, Duke Bogusław IV married Matilda, his stepmother's cousin. She was a daughter of John I, Margrave of Brandenburg, who was a brother of Barnim's third wife. Rymar stipulates that the marriage took place between 1275 and 1278. On 14 December 1278 Bogusław mentioned Matilda's brother, Margrave Conrad, as dilectissimus gener noster ${ }^{50}$. However, it is hardly possible to say anything for certain about the exact date of their marriage. According to the text from Chronica Principum Saxoniae, in 1264 Matilda's sister, Kunigunde, was married to Duke Bela of Slavonia:

48 D. Cramer, Grosses Pomerisches Kirchen-Chronikon, Bd. 2, Stettin 1628, p. 34; D. Cramer, O. Holder-Egger, Chronica Principum Saxoniae [in:] MGH, vol. 25, Hannoverae 1880, p. 480; Annales Colbacenses [in:] PU, Bd. 1, Abt. 2, p. 485. According to the annual, "Obiit Barnym dux Stetinensis Idus Novembris". According to this text, it was 13 November; PUB, Bd. 2, no. 1114. Duke Bogusław mentioned Barnim on 28 November 1278 as already dead and made a donation for the Cistercian nuns in memory of his father's soul; E. Rymar, Rodowód..., p. 145, ref. 291-292. Rymar provides sources that speak of Barnim's death.

49 PU, Bd. 2, nos. 1151, 1174, 1729-1730. Until 1295, both brothers, Barnim II and Otto I, regularly appear in the documents of Bogusław, who was their guardian after Barnim's death. The issue of their majority is, however, disputed, as in the document of 19 April 1280 we can read that "quod nos de consensus dilectorum fratrum nostrorum, Barnim et Ottonis". On 18 August 1280 we can also read about "mature consensus et bona volumptate nostrorum dilectorum fratrum, Barnym et Ottonis". Still, in the document of $1^{\text {st }}$ July 1295 Duke Bogusław IV mentioned his brother Barnim II as domicelli Barnym, and in the document of 12 July 1295 we can read that "dominus Buguzlaus, dux Slavorum at Cassubie, volens facere suo fratri karissimo domicello Ottoni”; see also: E. Rymar, Rodowód..., p. 28.

50 PU, Bd. 2, no. 1118, O. Holder-Egger, Chronica..., p. 479; see also: Regesten, no. 1165, p. 297. For more information about Duchess Matilda, see: idem, E. Rymar, Rodowód..., p. 160. 
"[...] filiam suam Conegudim maritavit Bele. [...] Mechtildam aliam filiam domino Barnem dedit. Hic Barnem obiit anno Domini 1278. [...] Hic Otto anno Domini 1266 estivo tempore in Pruciam contra Sarracenos vadens". We can assume that this marriage took place after 1264 , although we do not know for certain what it means exactly that "Mechtildam [...] domino Barnem dedit"51. Kunigunde was obviously married to Bela while Mechtild was "dedit". Maybe she was a minor and this notation was a mark of agreement until she reached a proper age for marriage. The relationship between Bogusław and Matilda, who was a relative of his stepmother, could testify to an attempt of rapprochement between the Pomeranian Duke and the margraves of Brandenburg. This marriage was probably initiated by Barnim and Matilda to bond the future ruler of Pomerania with Matilda's family and her descendants. If there was any open conflict between the stepson and stepmother, it started to grow after Barnim's death, and especially after Bogusław's first wife's death. However, this marriage did not last long, as before 1284 Duke Bogusław was married again to Margaret of Rügen ${ }^{52}$.

Duchess Matilda represented a different type of a policy than Duke Bogusław. And she did not intend to give up her reign so easily, as indicated by the mentions of her brother, Albert III, and her cousins in many Pomeranian documents. For example, Albert III was mentioned as a witness in 1279 with his sister, when she confirmed the city charter for Gartz (a city in Brandenburg, on the west bank of

51 O. Holder-Egger, Chronica..., pp. 479-480.

52 G. Labuda, Historia Pomorza, t. 1, cz. 2, Poznań 1972, p. 135. According to Labuda, after Barnim's death Duke Bogusław IV tried to maintain peace with the margraves of Brandenburg. In 1280 the bishop of Kamień Pomorski sold Świdwińska land (which belonged to the Pomeranian dukes) to the margraves of Brandenburg. Then, in 1283, Erich von Brandenburg was chosen as the Archbishop of Magdeburg. Erich was a half-brother of Bogusław's first wife, Matilda. According to Labuda, these two situations led to the formation of an anti-Brandenburg alliance in Rostock on 13 June 1283 (see: PU, Bd. 2, no. 1266); E. Rymar, Rodowód..., pp. 160-161; see also: idem, Wtadcy Brandenburgii (Askańczycy) na dzisiejszych ziemiach polskich, zwłaszcza $w$ Nowej Marchii i na Pomorzu w latach 1200-1319 (itinerarium), "Nadwarciański Rocznik Historyczno-Archiwalny" 2008, nr 15, p. 27. According to this researcher, a document from 1280 was misinterpreted - it could not be a sign of a conflict between the Margraviate of Brandenburg and Pomerania. This mistake was related to the place where the agreement was made: "in castro nostro Stargard" (see: PU, Bd. 2, no. 1168). Stargard was invaded by the margraves of Brandenburg in 1283 and this action was a mark of a conflict. From 1280 Stargard was located not in Pomerania, but in Mecklenburg. 
the Oder) ${ }^{53}$. Ueckermünde (situated in the district of Vorpommern-Greifswald) and the area of Gartz belonged to Duchess Matilda. She received those lands after her husband's death as financial protection. Matilda's cousins, margraves of Brandenburg-Stendal, Otto IV and Conrad, were involved in the Duchess's political affairs and in 1288 entered into an agreement with her stepson concerning her lands ${ }^{54}$. Her family obviously looked after her interests. On 18 February 1279, Duke Bogusław granted Gartz an unidentified waterbody aquam Maltze in order for the people living there to ba able to build a watermill ${ }^{55}$. Although the Pomeranian ruler tried to avoid conflict with his stepmother after his father's death, he could not do it forever. According to scholars, in 1279 Matilda's brother, Albert III, supported Archbishop-Elect Bernard von Wölpe. His decision resulted in a disagreement with Otto IV, Albert II of Brunswick, and Vitslav II of Rügen ${ }^{56}$.

53 PU, Bd. 2, no. 1149; J. Schladebach, Die Gründungsurkunde der Stadt Gartz a.d. Oder, Leipzig 1841, p. 26 ff.; B. Zientara, Rola Szczecina w odrzańskim i battyckim handlu zbożem XIII-XIV w., cz. 1, "Przegląd Historyczny" 1961, t. 52, p. 424. Gartz, like Szczecin, played a key role in merchant affairs until the end of the $14^{\text {th }}$ century. In 1278, Gartz and other Pomeranian towns such as Gryfino, Pyrzyce, and Stargard became part of the agreement between Duke Barnim and Margrave Conrad related to the territories between Choszczno and Stargard (in Western Pomerania); D. Lucht, Die Städtepolitik Herzog Barnims I. von Pommern 1220-1278, Köln-Graz 1965, pp. 25-28. According to scholar, the name Gartz means “castle-town”. In 1249, Duke Barnim granted Gartz town privileges. The precise date is not, however, certain - sources also mention the year 1240 . We know that in 1280 and 1288 there was a Slavic settlement there (see: PU, Bd. 1, no. 485; Bd. 2, no. 1167; Bd. 3, no. 1448); J.M. Piskorski, Miasta księstwa szczecińskiego do połowy XIV w., Poznań 1987, p. 55. The scholar states correctly that Ueckermünde, where Matilda made her confirmation of Gartz privileges, was a ducal residence. Already in 1270 Barnim mentioned "castro nostro Ukermunde" (see: PU, Bd. 2, no. 917); G.J. Brzustowicz, Wedlowie z Krepcewa, "Stargardia" 2003, t. 3, p. 82; the scholar asserts that a long time ago lands being part of this agreement were controlled by the margraves of Brandenburg - probably in 1269, when the Ascanians banished the Cistercians from Sowno.

54 PU, Bd. 3, no. 1472; see also: J. Walachowicz, Geneza i ustrój polityczny Nowej Marchii do poczatków XIV wieku, Warszawa-Poznań 1980, p. 62. According to the scholar, the Ascanian wives of the Griffins as well as members of the Piast dynasty were ambassadors of Brandenburg.

55 PU, Bd. 2, no. 1129.

56 J. Powierski, Krzyżacka polityka Przemysła II w pierwszym okresie jego aktywności politycznej [in:] Przemyst II. Odnowienie Królestwa Polskiego, red. J. Krzyżaniakowa, Poznań 1997, p. 117; E. Rymar, Klucz do ziem polskich, czyli dzieje Ziemi Lubuskiej aż po jej utratę przez Piastów i ugruntowanie władzy margrabiów brandenburskich, Gorzów Wielkopolski 2007, p. 102. 
Due to the escalating conflict with the Margraviate of Brandenburg, on 30 June 1280 Duke Bogusław contacted the Lübeck and Szczecin city councils, asking for help against the margraves of Brandenburg and calling their rule tyranny ${ }^{57}$. According to Kantzow, Albert III launched an attack against Duke Bogusław IV just after Barnim's death and took some of his lands (e.g. Pełczyce in Western Pomerania). The Duke's request for help might have been justified ${ }^{58}$. In the future the influence of the Hanseatic League in Western Pomerania was still growing, probably as a result of the anti-Brandenburg politics. Duke Bogusław started to replace Magdeburg rights with Lübeck law in the Pomeranian towns ${ }^{59}$. As the subsequent examples of documents show, tension between the Pomeranian Duke and the margraves of Brandenburg was continuously increasing. On 13 July 1280, Albert III confirmed an agreement between his cousins Otto IV and Conrad and Herman von Gleichen, Bishop of Kamień Pomorski. As a result of this arrangement, the former obtained land titles for Pełczyce, and the latter's rights to Kołobrzeg Land was confirmed ${ }^{60}$.

57 H. Lesiński, Rozwój stosunków polsko-hanzeatyckich w XIII wieku, "Przegląd Zachodni" 1952, t. 2, p. 141. Duke Bogusław in Lübeck had to confirm his father's donations and make some of his own for it was necessary to gain its support in the conflict with the margraves of Brandenburg; J. Osięgłowski, Polityka zewnętrzna księstwa Rugii (1168-1328), Poznań 1975, p. 91; D. Wybranowski, Poczatki świeckiego kręu wasali biskupa kamieńskiego Hermana von Gleichena (1251-1288/89) na tle jego działalności politycznej i kolonizacyjnej. Przyczynek do dziejów państwa biskupiego w XIII w., część 2 (1275-1280), "Studia z Dziejów Średniowiecza" 2004, t. 10, p. 354. According to the scholar, those letters were evidence of the escalation of the conflict between Pomerania and Brandenburg (see also: PU, Bd. 2, nos. 1164-1165).

58 T. Kantzow, Chronik..., Bd. 2, p. 111; see also: PU, Bd. 2, nos. 1164-1165.

59 E. Rozenkranz, Recepcja prawa lubeckiego w miastach nadbattyckich, Gdańsk 1967, p. 187; J.M. Piskorski, Prawo magdeburskie w miastach Pomorza Zachodniego od XIII do XVIII wieku [in:] Niemcy-Polska w średniowieczu. Materiaty z konferencji naukowej zorganizowanej przez Instytut Historii UAM w dniach 14-16 XI 1983 roku, red. J. Strzelczyk, Poznań 1986, pp. 261-262.

60 PU, Bd. 2, no. 1168. This agreement guaranteed peace between the margraves and Bishop Herman, who just wanted to keep his rule and territories. Perhaps the agreement was proof of an invasion of Margrave Albert on the lands of Duke Bogusław after Barnim's death. Bishop Herman did not want to lose his lands and accepted the agreement in 1280. As he was a cousin of the margraves of Brandenburg, there was nothing unusual in the fact that he was mentioned frequently in documents with them (see also: no. 1253). In the document of Margraves Otto IV and Conrad in 1283, Bishop Herman was called his beloved cousin (see also: no. 1210). In Bogusław's document from 1281, Margrave Albert appeared as a witness. The Pomeranian duke gave Bishop Herman half of a village. He probably wanted to gain his favour. 
On the 13 June 1283, the Rostock Peace Treaty was agreed by the Baltic cities of Lübeck, Wismar, Rostock, Stralsund, Greifswald Szczecin, Demmin, and Anklam, as well as Duke John I of Saxe-Lauenburg, the Mecklenburg prince, Bogusław IV of Pomerania, and Vitslav II of Rügen ${ }^{61}$. This alliance was clearly directed against the Margraviate of Brandenburg. Then, on the 28 October 1283, the margraves of Brandenburg attacked Stargard and Gryfino with the surrounding castles ${ }^{62}$, supported by the Knights Hospitaller from the village of Copam (in Stargard Land), the Knights Templar from Rurka (in Western Pomerania), the Cistercians from Kołbacz (in Western Pomerania), and many of their noblemen and vassals. As a result, the area of Pyrzyce and Stargard was ravished. Duke Bogusław was in alliance with the Pomeranian Duke Mestwin II and Duke Przybysław II, who was granted Białogard by Bogusław. Przybysław, afraid of losing his lands, deserted Duke Bogusław after 1284 and became a vassal of Margraves Otto IV and Conrad I. His decision, however, was made too soon - Bogusław regained his lands and expelled disloyal Przybysław ${ }^{63}$.

One of the crucial roles in this conflict was played by cities of Western Pomerania. Duke Bogusław, having gotten in debt, had to strengthen his financial position, and in order to do so granted town

61 Ibidem, no. 1266.

62 E. Rymar, Poczatki Chojny (1235-1244) w ramach miejskiej reformy $w$ księstwie Barnima I Zachodniopomorskiego, "Materiały Zachodniopomorskie" 1987, t. 33, pp. $188 \mathrm{ff}$.

63 F. Zickermann, Das Lehrverhältnis zwischen Brandenburg und Pommern im dreizehnten und vierzehnten Jahrhundert, "Forschungen zur Brandenburgischen und Preussichen Geschichte” 1891, Bd. 4, pp. 62-63; see also: PU, Bd. 2, no. 1312 (1284); P. von Niessen, Geschichte der Neumark..., pp. 272 ff.; E. Rymar, Udziat rodu Wedlów w ekspansji margrabiów brandenburskich na Pomorze Środkowe i Wschodnie w latach 1269-1313 [in:] Pomorze stowiańskie i jego sqsiedzi X-XVw., red. J. Hauziński, Gdańsk 1995, p. 49. Many Pomeranian territories, such as Dobra Nowogardzka, Police, or castles in Trzebiatowo and Płoty, have been taken over by the Brandenburgian noble families such as Behr, Greiffenberg, and Wedel; B. Śliwiński, Poczet ksiażat gdańskich. Dynastia Sobiesławiców XII-XIII wieku, Gdańsk 1997, pp. 68-69. Duke Przybysław II was married to Cathrine, a daughter of Duke Mestwin II and a relation of Bogusław IV. As a result of the conflict between the Duchy of Pomerania and the Margraviate of Brandenburg, Duke Przybysław lost Białogard; D. Wybranowski, Upadek polityczny księcia Przybysława II, pana na Dobrej, Białogardzie i Olesznie, a sprawa likwidacji enklaw wptywów brandenburskich na Pomorzu Zachodnim do 1291-1292 roku, PZ 1999, t. 14, pp. 7-8, 11; D. Wybranowski, Zakony rycerskie w polityce biskupa kamieńskiego Hermana von Gleichena w latach 1261-1283, "Gdańskie Studia z Dziejów Średniowiecza” 2000, t. 7, p. 306; G.J. Brzustowicz, Wedlowie z Krepcewa, "Stargardia" 2003, t. 3, pp. 82-83. 
privileges to such cities as Szczecin, Gartz, Gryfino, or Pieńkuń ${ }^{64}$. According to scholars, after the conclusion of the Peace Treaty of Vierraden in 1284, improved relations started developing between another ally of Bogusław IV, Vitslav II, and the margraves of Brandenburg. At that time Duke Bogusław was probably already married to Vitslav's daughter Margaret. Still, it needs to be remembered that we have no information about the exact date of death of his first wife Matilda ${ }^{65}$. On 13 August 1284, Duke Bogusław signed the Peace Treaty of Vierraden (in Brandenburg), whereby he upheld his custody of his step-siblings. This agreement was undoubtedly made possible by the activities of the Lübeck and Szczecin city councils ${ }^{66}$. However, due to Duchess Matilda's efforts the situation was about to change.

On 8 September 1288, Margraves Otto IV and Conrad made an agreement with Duke Bogusław IV concerning the lands that passed to Duchess Matilda after her husband's death ${ }^{67}$. Until 1292 there was no mention of Matilda in any documents. Meanwhile, Duke Bogusław again made decisions that went against the interests of the margraves of Brandenburg - for instance, in 1287 he signed a Peace Treaty of Słupsk with another Pomeranian Duke Mestwin II and Przemysł II, Duke of Greater Poland ${ }^{68}$, according to which if both Mestwin II and Przemysł II were dead, Gdańsk was to pass on to Bogusław IV or his descendants ${ }^{69}$.

On 18 June 1292, Matilda attempted to bribe and co-opt members of the Szczecin city council - and she indeed reached an understanding with them. She had the support of her brother Albert III and her cousins Otto IV and Conrad ${ }^{70}$, with whom she had a mutual agreement - both sides were obliged to help each other in need. Crucially,

64 G. Labuda, Dzieje Szczecina, t. 2, Warszawa-Poznań 1985, pp. 93-94.

65 J. Osięgłowski, Polityka zewnętrzna..., pp. 91-92.

66 PU, Bd. 2, no. 1312.

67 Ibidem, Bd. 3, no. 1472; J. Walachowicz, Geneza i ustrój polityczny..., p. 62.

68 PU, Bd. 3, no. 1441; G. Labuda, Historia Pomorza..., t. 1, cz. 1, p. 535; D. Wybranowski, Zakony rycerskie w polityce..., p. 307; for more see: idem, Poczatki świeckiego kregu wasali biskupa kamieńskiego Hermana von Gleichen (1251-1288/1289) na tle jego działalności politycznej i kolonizacyjnej. Przyczynek do dziejów państwa biskupiego w XIII wieku, część 3 (1281-1288), "Studia z Dziejów Średniowiecza" 2006, t. 12, p. 445.

69 B. Śliwiński, Mściwoj II (1224-1294) ksiaże wschodniopomorski (gdański), Warszawa 2016, pp. 325-348. Błażej Śliwiński presents the political relationships between Duke Mestwin II, Bishop Herman von Gleichen of Kamień Pomorski, Duke Bogusław IV, and Duke Przemysł II between 1287-1289.

70 PU, Bd. 3, no. 1609. 
she also promised openly to support her brother Albert III's and her cousins' resolutions concerning Western Pomerania. In 1295, Adolf of Germany made a decision to intervene in this conflict. The margraves of Brandenburg were granted rights to the territory of Pomerania, while Duke Barnim II and Otto to numerous lands in Western Pomerania. After the death of Duke Barnim II, on 28 May 1295, Western Pomerania was divided between Bogusław IV and his stepbrother Otto ${ }^{71}$. Then, on 24 April 1297, Margrave Albert III again expressed support for his sister Matilda and reminded, in a document to the members of the Wedel family, that after the death of Duke Barnim I the lands of Szczecin passed on to the Duchess and her sons. Probably as a result of a misunderstanding they believed that the lands belonged to the Margraviate of Brandenburg ${ }^{72}$. Duke Bogusław decisively resisted the Margraviate of Brandenburg until the end of his life. He pursued a pro-Polish policy and supported activities of the King of Poland Władysław the Elbow-High in Eastern Pomerania. This led to the invasion of the margraves of Brandenburg on Pomerelia (Eastern Pomerania) and Duke Bogusław's district in 1308. The invaders destroyed Kamień Pomorski, a Pomeranian bishopric ${ }^{73}$.

Bogusław's stepbrother Otto stayed under Duchess Matilda's control until her death. Towards the end of the $13^{\text {th }}$ century and in the early $14^{\text {th }}$ century the Duchess was mainly interested in issues connected with her city of Gartz, which was allowed to collect road tax from merchants and was granted a privilege of grain purchase ${ }^{74}$. Matilda's son, Duke Otto, also gave Szczecin permission to build bridges and a stone levee on a road to Dabie ${ }^{75}$. The Duchess was mentioned frequently with her children in numerous documents as

71 Ibidem, Bd. 4, no. 4039. Among the main witnesses to this agreement were citizens of Pomeranian cities and members of the chivalry. Both dukes had to promise that they would keep peace and the unity of Western Pomerania. Otto became the ruler of Szczecin, and Bogusław of Wolgast (in Mecklenburg-Vorpommern). However, until the death of Duke Bogusław we can observe a division of the Duchy of Pomerania, despite the previous assurances of the brothers. See: J. Spors, Rzekome tytuty prawne Brandenburgii do Pomorza Gdańskiego opierajace się na potwierdzeniach z 1231 i 1295 r. [in:] Personae - colligationes - facta, Toruń 1991, pp. 246-247; see also: PU, Bd. 1, no. 279; Bd. 3, no. 1707.

72 PU, Bd. 3, no. 1804; J. Walachowicz, Geneza i ustrój polityczny..., p. 62.

73 B. Dopierała, Polskie losy Pomorza Zachodniego, Poznań 1970, pp. 72, 74-75;

E. Rymar, Udziat rodu Wedlów w ekspansji..., pp. 56-58.

74 PU, Bd. 2, no. 943; Bd. 4, nos. 1790, 1791, 2028.

75 Ibidem, Bd. 4, no. 1912. 
a beloved mother of her sons. After the death of Barnim II, she was mainly mentioned in Otto's documents ${ }^{76}$.

Matilda's family background precluded her from making an alliance with Bogusław IV, whose intention was to unite the Duchy of Pomerania. Both of them wanted to keep their sovereignty and rule without sharing authority. During her life, Matilda had the support of the margraves of Brandenburg; a number of her relatives actively participated in politics. Her presence in the Pomeranian documents testifies to her strong desire to be involved in the internal affairs of the duchy. Though also a devoted mother, her true self was a strong and independent woman and cunning ruler doing her utmost to efficiently administer her duchy. Her joint reign with Bogusław was, however, impossible - a circumstance which finally led to the division of the Duchy of Pomerania in 1295.

\begin{abstract}
Stepmother and stepson: Duchess Matilda in the power struggle after the death of her husband Barnim I, the Duke of Pomerania
\end{abstract}

This essay presents the diplomatic relations between the Pomeranian Duke Bogusław IV and his stepmother, Duchess Matilda. Bogusław was the first son of Duke Barnim I and his second wife, Duchess Margaret of Mecklenburg. The first aim is to describe some general information relating to their personal life. Another crucial objective is to explore in greater detail the political situation in the Duchy of Pomerania towards the end of the $13^{\text {th }}$ century and in the early $14^{\text {th }}$ century. This is a complex problem because of the numerous conflicets between Duke Bogusław IV and the Margraviate of Brandenburg. His stepmother, Duchess Matilda, was a daughter of Margrave Otto III of Brandenburg. This fact had an immense influence on their diplomatic relations. In 1295, the Duchy of Pomerania was divided between Duke Bogusław IV and his half-brother, Otto I. According to this agreement, Bogusław received Wolgast, and Otto Szczecin. The paper shows that in all likelihood Duchess Matilda contributed to this division of the duchy.

76 Ibidem, no. 1718: "Karissima mater nostra, domina Mechtilde, inclyta Slavorum ducissa"; no. 1720: "Matris nostre amantissime Mechtildis inclite Sclavorum ducisse". Similar epithets, see: nos. 1895, 1912, 2087, 2142, 2251, 2309, 2606. 